\title{
Research on Psychological Health Education of College Students under Positive Psychology Model
}

\author{
Yihui Li \\ Department of Psychology \\ School of Humanities and Social Sciences \\ Gannan Medical University \\ Ganzhou, China 341000
}

\author{
Xiaozhen Liu \\ Department of Psychology \\ School of Humanities and Social Sciences \\ Gannan Medical University \\ Ganzhou, China 341000
}

\begin{abstract}
The psychological health education of college students is important in higher education. It is an important task of colleges to train college students' healthy psychology and make them form good psychological traits. The development and flourish of positive psychology provides theoretical basis for psychological health education of college students. The construction of course system in psychological health education of college students under the perspective of positive psychology should highlight positive concept. Course framework runs through the training of college students' positive quality, the experience of college students' positive psychology and the creation of positive course environment. Required course combines with optional course and classroom teaching combines with practical experience. Positive psychological consultation should run through psychological health education.
\end{abstract}

Keywords—positive psychology; college students; psychological health education; course system

\section{INTRODUCTION}

The psychological health education in colleges has had a history of more than twenty years. Although great results have been achieved in scientific research or practice of psychological health education, the integral level of college students' psychological health is not improved. An investigation on college students reveals $20 \%$ of college students have psychological problems [1]. The psychological health education in colleges solves the problems of a few students and neglects the demands of most students' psychological development [2]. Psychological health education should promote and achieve psychological development and train positive quality of people. Positive psychology represented by Martin Seligman centers on the research of people's development potential, virtue and strength instead of positive, disabled and morbid psychology[3], providing new perspective for psychological health education in colleges. This paper deeply investigates problems in psychological health education, integrates positive psychology in it and proposes effective countermeasures and suggestions more suitable for psychological health education of college students.

\section{Problems in Psychological Health EduCAtion COURSE IN COLLEGES UNDER THE PERSPECTIVE OF POSITIVE PSYCHOLOGY}

Influenced by traditional psychology, the psychological health education of college students analyzes and solves psychological problems and disorders. Positive psychology aims at ordinary people with average level of psychological health and promotes people to discover and appreciate people's potential, motivation and ability. The psychological health education under the perspective of positive psychology has problems in teaching and psychological consultation.

\section{A. Teaching Objectives}

The teaching objectives of psychological health education are divided into three levels. The first-level objective focuses on preventive education and aims at all the students, the development of students' potential and training of psychological quality; the second-level objective focuses on the solution to psychological problems, gives guidance and consultation for general psychological problems and eliminates students' psychological disorder; the third-level objective focuses on treatment of psychological disorder and illness [4]. According to the investigation, most objectives of psychological health education course of college students are at the second level. The psychological health education of college students neglects the development objective.

\section{B. Teaching Methods}

The psychological health education of college students is required course attended by a large number of students. Infusion education and single teaching method lead to tedious classroom climate and poor effect. It lacks experience-oriented education. Teachers of psychological health education course should pay more attention to emotional and psychological experience of college students.

\section{Teaching Contents}

Most knowledge of psychological health education received by college students is negative, such as how to recognize common psychological disorder, how to differentiate normal psychology from abnormal psychology and how to prevent it. Students think psychological health education is to 
help them to prevent mental disease and only patient needs psychological education by mistake. It will bring negative suggestion and cause anxiety. Students try to find the symptom conforming to the psychological problems and how to solve them instead of focusing on how to improve their psychological quality.

\section{Psychological Consultation Pattern Is Unreasonable}

Psychological counseling organizations have been established for college students, including psychological disorder consultation, psychological crisis intervention, developmental counseling, psychological counseling for learning and examination. The psychological consultation in most colleges tends to pathological treatment. School psychologists focus on students with psychological disorder and their psychological problems. The psychological consultation in colleges should have rich contents and forms to serve all the students, effectively prevent, guide and correct students' psychological problems or problems may happen, provide channel for students to vent annoyance and depression, in order to promote students' psychological development and sound personality and maintain their psychological health.

\section{ENLIGHTENMENT OF POSITIVE PSYCHOLOGY ON} Psychological HeALTH EdUCATION OF COLLEGE STUDENTS

In order to make the service subject learn to create, give and acquire positive strength, psychology should treat people positively, create positive spirit, provide positive opportunity and affirm positive values. The positive psychology has provided helpful enlightenment for course system in psychological health education of college students.

\section{A. Positive Psychology Lays a Theoretical Foundation for Training of Developmental Psychological Quality of College Students}

The research topics of positive psychology include happiness, positive emotion, immersed experience, optimistic explanatory style, emotional intelligence, positive traits, relationship, ego and changes [5]. It lays a good theoretical foundation for improvement of developmental psychological quality of college students. In psychological health education, educators should guide students to discover strengths, arouse potential and build self-esteem and self-confidence with strengths and virtues, experience happiness and values in growth.

\section{B. Positive Factor of Human Is the Practice Foundation to Shape Positive Psychological Quality of College Students}

It is observed in positive psychology that human nature is positive [6] and the self-actualization needs in Maslow's Hierarchy of Needs. But the positive nature will not express voluntarily in any case. The psychological health education course for college students on the basis of positive psychology provides positive environment for the growth of positive nature and effective ways for them to find positive quality.

\section{CONSTRUCTION OF COURSE SYSTEM IN} PSyChOlOGiCAL HEALTh EdUCATION OF COLLEGE STUdENTS UNDER THE PERSPECTIVE OF POSITIVE PSYCHOLOGY

According to positive psychology, the psychological health education course should find and explain positive aspects of problems from the positive perspective, use positive ways to train positive quality, and positive attitudes to shape positive life [7]. Therefore, the psychological health education of college students on course provision should infiltrate positive concept and combine optional course with required course, theory with practice.

\section{A. Positive Concept Runs through the Course System in Psychological Health Education of College Students}

According to positive psychology, psychological health education course of college students should train their positive personality and pay attention to students' positive psychological experience in course and daily life. Psychological health education course should be developed from many perspectives to train students' positive strength in creating happy life.

1) Teaching objectives: Train positive psychological qualities of college students on the basis of positive concept, including positive cognitive emotion, volitional quality and moderate motivation system, good ability and personality. The positive psychological qualities help to stimulate potential of college students and improve their subjective well-being. Psychological health education is a process of help of others to mutual help to self-help. Therefore, teachers should promote the positive psychological growth of college students through positive guidance and education.

2) Course contents: The comprehensive development direction of course contents of positive psychology is embodied. According to the three-level objectives of psychological health education of college students, increase developmental objectives, train positive emotion and personality, develop psychological potential and develop positive psychological quality of college students.

3) Course provision: It should be systematic and grasp the psychological characteristics of students at different grades. The psychological health education courses are provided according to psychological problems and development of students at different grades, such as career planning and interpersonal relationship for freshman, learning psychology and stress management for sophomore, psychology of marriage and career development for junior and employment psychology and role anxiety for senior. Courses relevant to positive psychology involving happiness, self-esteem, understanding, emotion, emotional quotient, immersed experience, positive personality, positive ego and sense of happiness can run through the college days of four or five years to make the psychological health education of college students more pertinent and effective. 


\section{B. Two Combinations Run through the Basic Structure of Psychological Health Education of College Students}

Scientifically arrange psychological health education course and combine required course with optional course, classroom teaching with practical experience to integrate positive psychology in course and teaching practice.

1) Combine required course with optional course: The psychological health education courses of college students can be required course and optional course. The former train mental health knowledge, skills and quality of college students provided for all the students; the latter expand psychological health education subject, further deepen knowledge and skills of psychological health and excavate potential of students and develop their positive quality. Different optional courses can be provided to improve positive psychological quality according to requirements of students at different grades.

2) Combine classroom teaching with practical experience: Psychological health education courses of college students are practical. Positive psychology emphasizes the importance of subjective experience. The teaching of psychological health education course of college students, teachers should teach knowledge and let students apply the knowledge to daily life. The psychological quality and ability of students will be promoted through experiencing the internal psychological course and making them have profound emotional experience in affective interaction and collision of thought. Specifically speaking, the understanding and experience of students on the course can be further deepened through group guidance, role play and other activities.

\section{Positive Psychological Consultation Runs through Psychological Health Education in Colleges}

Psychological treatment tends to pathological treatment: evaluate and treat problems of patients and research negative influences of tense stimulation on the psychology of patients [8]. It is proposed in positive psychology that the technology strategies of good psychological treatment include: care, authority, image, appetency, dedication, trust, openness, proper naming of problems and communication skills [9]. In positive psychology, it is the best strategy in psychological treatment to train positive strength and quality of people. Treatment should not first eliminate the existing disorder of patients but motivate abilities and self-help potential of patients. Objects of psychological treatment should be regarded as people instead of carriers of disease.

Positive psychological consultation can effectively prevent and treat psychological illness through excavating strength of individuals. The positive significance of problems is pursued through two aspects: The first is to explore the root cause of problems; the second is to acquire positive experience to train positive strength of individuals [10]. College students have high quality and ability in understanding and acceptance and self-development consciousness. Therefore, it is more effective to solve psychological health problems of college students through positive psychological consultation. Individual counseling of college students should carry out according to characteristics of school, grade, class and students. The psychological consultation of college students is regarded as a correlative system because all aspects of psychological consultation relate to, influence and promote each other.

\section{CONCLUSION}

Positive psychology is a beneficial complement of traditional psychology and has positive referential value for the construction of course system in psychological health education of college students. Defects inevitably exist in this new-rising subject. The academic world is at the exploratory stage to construct course system in psychological health education of college students. The course system in psychological health education of college students under the perspective of positive psychology is preliminarily discussed in this paper.

\section{REFERENCES}

[1] Zhang Yufang, Cheng Qixiu, Li Minqi. Investigation and Analysis on Mental Health Status of Contemporary College Students [J], Study Monthly, 2007(4): 11-14

[2] Liu Xiangping, Cao Xinmei. Infuse Positive Psychology Factors into Psychological Health Education [J], Educational Research, 2008(2): 14 17

[3] Zhou Qian, Shi Guoxing. Introduction to Positive Psychology [J], Chinese Mental Health Journal, 2006(2): 33-36

[4] Zhao Xia. Reflection on General Survey of Psychological Health of College Students [J], Journal of Technology College Education, 2008(5) 19-21

[5] Ren Jun. Positive Psychology [M], Shanghai: Shanghai Educational Publishing House, 2006

[6] Meng Wanjin. Positive Mental Health Education [M], China Light Industry Press, 2008

[7] Ren Jun. Analysis on Positive Education Thought in the West [J], Studies in Foreign Education, 2006, (5): 65-69

[8] Cao Hongwei. Enlightenment of Positive Psychology on Psychologica Health Education in School [J], Folk Art and Literature, 2011(17): 22-24

[9] Siligman, P.E., Csikszentmihalyi M. Positive Psychology: An Introduction [J].American Psychologist, 2000, 55 (1) : 5-14.

[10] Csikszentmihalyi M. Flow: The Psychology of Optimal Experience [M].New York: Harper \& Row, 1997:13 